\title{
INTEGRATED LICENSING POLICY WITH ELECTRONIC POLICY:STUDY IN THE DEPARTMENT OF CAPITAL INVESTMENT AND INTEGRATED SERVICES OF JEMBER INDONESIA
}

\author{
By: NadyaAudyna. Itok Wicaksono (correspondence author) \\ Email: itokwicaksono@unmuhjember.ac.id \\ Program Studi Ilmu PemerintahanFakultas Ilmu Sosial dan Ilmu Politik \\ Universitas Muhammadiyah Jember
}

Received: 10 February 2019, Revised: 22 February 2019, Accepted: 24 February 2019

\begin{abstract}
Electronic Integrated Licensing Services or Online Single Submission, hereinafter abbreviated as OSS, are Business Licenses issued by OSS Institutions for and on behalf of ministers, heads of institutions, governors, or regents/mayors to business actors through integrated electronic systems. Jember Regency as one of the Regencies that have implemented OSS,began to implement it in 2018. This service is a government effort to simplify business licensing and create an integrated licensing service model that is fast, inexpensive and certain. In this study the researchers used the Edward III Theory of communication, bureaucratic structure, disposition and resources. The results of this study show that Jember'sInvestment and Integrated One-Stop Service is not yet optimal in carrying out its duties, because in the bureaucratic structure no SOP for this policy resulting in overlapping responsibilities because the organizers are responsible for serving Single Online services Submission (OSS) also serves services manually. In addition, even though the Jember regency government has conducted licensing related online, there are still many people and business people from those who are processing the permits to the One Stop Integrated Investment and Service Office of Jember Regency.
\end{abstract}

Keywords: policy implementation, Online Single Submission (OSS)

\section{INTRODUCTION}


The One Stop Integrated Service aims to create changes in public services where people who had to go to several offices and go through a number of processes, but the community now only needs to go to one office so the community does not need to take much time in the permit process. However, OneStop Integrated Services are considered not optimal because there are still unintegrated, sequential licensing problems, not all using information technology (online), unclear completion time and licensing fees, complicated requirements, and paradigms in the bureaucracy's own body as a licensor and have not served the community wholeheartedly. The government seeks to improve the standard of business licensing services that are efficient, easy and integrated without ignoring good governance. The government has made the latest breakthrough in public service innovation towards good governance by implementing E-Government (electronic-based government services) in every public service and improving the investment climate in Indonesia by launching a Licensing Service Policy Trying to Be Integrated Electronically or Online Single Submission, hereinafter abbreviated as OSSOSS is a system of business licensing that is integrated electronically with all state ministries/institutions (KL) to regional governments (pemda) in Indonesia. Online Single Submission (OSS) aims to summarize time and bureaucracy in the business licensing process. This policy was taken by the government as an effort to improve the national economy through the growth of the business which has so far complained the length of time and the chain of bureaucracy to be passed through to start a business. OSS requires every entrepreneur, both a business entity and an individual, to have a Business Registration Number (NIB), becauseNIB is a business identity and is used by businesses to obtain business licenses and commercial/operational permits. In addition, the main advantages in owning NIB isthat business actors or investors managing business licenses will not be complicated nor spend a lot of time,and that business people need not to carry too many required documents to issue a business license. Simply use NIB as one of the required documents accompanied by some supporting documents needed. 
With the existence of a Business License Number (NIB), it is no longer necessary to bother to administer a number of other licenses because NIB has provided an easy role as an official license to replace the SIUP (Trading Business License), TDP (Company Registration), Importer Identification Number (API), and Customs Access. OSS has a legal umbrella in the form of Presidential Regulation Number 91 of 2017 concerning the Acceleration of Business Execution, then the government issued Government Regulation Number 24 of 2018 concerning Business Licensing Services Integrated Electronic. The OSS system is expected to be the main gate of the government service system.

Jember'sOne Stop Investment and Service Office has implemented the Online Single Submission (OSS) application that has been implemented in June 2018. The Regional Government is able to support OSS because it supports Jemberto be a developed city.With this application the investment and services of the Investment and One-Stop Integrated Service Office are increasing. While the concept developed in Online Single Submission (OSS) is the integration of licensing services between the central and regional governments online. The presence of Online Single Submission (OSS) answers the licensing problems so far about the slow licensing services of Jember Investment and Integrated OneStop Service. The government has a One Stop Integrated Services policy that must be implemented by both the central and regional governments to speed up licensing. The Minister and Head of Institutions, Governors, Regents/Mayors have even delegated their licensing authority to the Investment and One-Stop Services in each region. With the Online Single Submission (OSS) system, the longest licensing process will take 60 minutes to complete.

Investors or people who want to invest in Jember Regency can go directly through the website provided. However, people can come directly to the One Stop Integrated Service. This One-Stop Integrated Services provide services such as self-service, assisted services, priority services, investment general consultations and business clinics. The hope of the Jember government by 
By: Nadya Audyna, Itok Wicaksono Integrated Licensing Policy With Electronic Policy: Study In The Department Of Capital Investment And Integrated Services Of Jember Indonesia

implementing OSS, in addition to facilitating services and licensing processes quickly and cleanly, is also expected to increase investment in Jember.

\section{LITERATURE REVIEW}

\section{Policy Implementation}

Implementation of policy in principle is a way for a policy to achieve its objectives. Lester and Stewart were quoted (2003), explaining that policy implementation "... seen in a broad sense is a legal administration tool in which various actors, organizations, procedures and techniques work together to implement policies to achieve the desired impact or goal" ( Lester and Stewart in Winarno, 2002: 101-102). So policy implementation is actions taken by the government to achieve the goals set in a policy decision. However, the government in making policies must also examine in advance whether the policy can have a bad or no impact on the community. It is intended that a policy does not conflict with the community especially to the detriment of society. Implementation of policy according to Nugroho(2003), there are two choices for implementing it, namely directly implementing it in the form of programs and through formulation of derivative policies or derivatives of these policies (Nugroho, 2003: 158). Therefore, the policy implementation described by Nugroho is two choices; the first one directly implements the program and the second option through policy formulation. From the explanation above, it can be seen that policy implementation is an action or implementation of a decision determined by the government in order to achieve a goal. Moreover, the related policy regarding Electronically Integrated Business Licensing Services is a policy made by the government in order to accelerate the business licensing process that exists in every One Door Integrated Service. The explanation above argues that the success of a policy implementation will be determined by many variables, each variable is interconnected with one another. For this reason, the researchers use the theory of George C. Edward III. In the view of Edward III, the implementation of the policy is influenced by 4 (four) indicators, namely 
By: Nadya Audyna, Itok Wicaksono

Integrated Licensing Policy With Electronic Policy: Study In The Department Of Capital Investment And Integrated Services Of Jember Indonesia

Communication, Bureaucratic Structure, Resources and Resources, this is intended to answer the research problems that researchers carry out.

\section{Bureaucratic Structure}

According to Edward III (1980: 11) in Arifin Tahir (2015: 70-71) explained that although the resources for implementing policies are sufficient and the implementers know what to do and are willing to implement it, implementation is still hampered by inefficiency of the bureaucratic structure . Organizational fragmentationcan hamper the coordination needed for the success in implementing a policy that requires cooperation with many people. This leads to wasting scarce resources, closing opportunities, creating confusion, driving policies to produce cross goals, and causing important functions to be forgotten. As administrators of organizational unit policies, they build standard operating procedures or SOPs to handle routine tasks as they usually handle. Unfortunately, the standards are designed for running policies and are not able to function properly for new policies so that changes, delays, renewals or actions that are not desired are difficult. Standards are sometimes more inhibiting than helping policy implementation. The policy implementers will know what to do and have the desire and resources to carry out policies, still they will be hampered by the implementation process by the organizational structure, different bureaucratic fragmentation will hinder the implementation of policies, waste of resources, cause expected actions, hinder coordination, due to the policy process on the opposite purpose, and because some policies failed.

According to Edward III (1980: 10) in Arifin Tahir (2015: 66) suggests that important resources include staff in the right size with the necessary expertise, information that is relevant enough about how to implement policies in other adjustments involved in the implementation of the authority to ensure that this policy is carried out all as intended and various facilities (including buildings, equipment, land and supplies) in it or by providing services. Insufficient resources will mean that the law will not be enforced. Services will not be provided, and 
proper regulations will not be developed. The resources owned by the organization are interpreted as organizational capabilities so that implementing resources are understood as implementing capabilities. Then, the implementation of the policy is influenced by the ability of the implementer which includes the ability of resources, commitment, authority, coordination between implementers and the culture adopted. This is in line with Grindle's view, Mmazmanian, who explained that policy implementation cannot be separated from its implementation. In terms of implementing policies based on the resources they have, with all their behavior. Resources in an organization include the capacity of the organization and the people involved, quality and quantity, authority possessed, and organizational culture. In addition, if a policy is implemented more than one organization, organizational resources also include cooperation and coordination. Resource factors have an important role in policy implementation, because however clear and consistent the provisions or rules of a policy, if the personnel responsible for implementing the policy lack the resources to do work effectively, then the implementation of the policy will not effective. In implementing compliance is measured by looking at the suitability of implementing behavior with obligations carried out. Resources that can support the implementation of tangible policies, such as human resources, and budgetary resources, equipment resources, information resources and authority. For Human Resources itself, it plays a very important role in the implementation of Online Single Submission (OSS) in Jember Investment and Integrated Services.

The Budget Resources, it can support the implementation of the Online Single Submission (OSS). Equipment Resources also become a supporting factor in the implementation of Online Single Submission (OSS). Furthermore, the authority itself becomes a separate force for the relevant OPD to carry out OSS. Human resources are one of the variables that affect the success and failure of implementation. Implementation is very dependent on human resources (apparatus), thus human resources in the implementation of policies must be sufficient and have the expertise and ability to carry out tasks, recommendations, 
orders from their superiors (leaders). Therefore, human resources must have accuracy and feasibility between the number of staff needed and the expertise they have in accordance with the work tasks they handle.

Budget resources are a resource that affects implementation after the existence of human resources, the limited available budget causes the quality of public services that must be given to the community is also limited. The limited budget causes the disposition of the lower actors and even the goal displacement will be carried out by the actors towards the achievement of the stated goals and objectives. Equipment resources are the means used for the operationalization of the implementation of a policy that includes buildings, land and facilities; all of which will facilitate service delivery in policy implementation. The limited equipment facilities needed in implementing policies lead to failure to implement policies, because with limited facilities it is difficult to obtain accurate and reliable information that will be very detrimental to the implementation of accountability. Information resources and authority are also important in implementation. Information about willingness or ability from various parties involved in policy implementation is intended to avoid the implementers from making a mistake in interpreting ways to implement it. Authority is also another resource that influences the effectiveness of policy implementation. Edward III confirms that the authority is sufficient to make their own decisions will affect the institution in implementing a policy(Edward III, 1980: 103).

\section{Disposition}

Edward III (1980: 11) in Arifin Tahir (2015: 68) argues that implementing attitudes is the third important factor in the approach regarding the study of public policy implementation. If the implementation of the policy is expected to take place effectively, policy implementers do not have to have the capability to implement it, but they must have the desire to. Most implementers use as much authority as possible in implementing a policy. One reason for this is due to their independence in making policies. Another reason is the complexity of the policy itself. Although sometimes the implementers use their authority as they depend on 
their disposition that refers to these policies, but in the end their attitude influences their view of the policy and how they see the policy which could have an impact on the interests of individuals and their organizations.

Disposition is the characteristics possessed by implementing policies, dispositions such as commitment, honesty, and democratic nature. If the implementer of the policy has good characteristics, then he will implement the policy well in accordance with the objectives and desires of the policy maker. According to Van Meter and Van Horn, there are three types of elements that can affect disposition, among others: "... cognition, understanding and understanding of policy, the direction of their response whether to accept, neutral or reject (acceptance, neutrality, and rejection), intensity of policy " (Van Meter and Van Horn in Widodo, 2007: 105). Elements that can influence disposition are knowledge, where knowledge is a fairly important element because with high knowledge possessed by the apparatus can help implement the implementation. Deep understanding can also help create and implement the policy in accordancewith the objectives to be achieved. Community response can also determine the success of an implementation, because it can determine the attitude of whether the community accepts, is neutral or rejects. In addition, commitment from implementers, especially the government, can be seen from the existence of a licensing service policy that requires the provision of electronically integrated services.

\section{Communication}

According to Edward III (1980: 10) in Arifin Tahir (2015: 62-66) arguing that policy implementation can run effectively, it must be responsible for the implementation of a policy must know what to do. Orders to implement policies must be clearly, accurately and consistently delivered. This communication factor shows the role as a reference so that policy implementers know exactly what they are going to do. This means that communication can also be stated with orders from superiors to implementers of policies so that the implementation of the policy does not go out of the desired target. Policy communication has several 
types of dimensions, including the dimensions of transmission, clarity and consistency. The transformation dimension requires that public policy can be transformed to implementers, target groups and other parties related to policy. The dimension of clarity requires that policies that are transmitted to implementers, target groups and other parties who have a direct or indirect interest in the policy can be clearly accepted so that they can be identified as intentions, goals and objectives. Furthermore, consistency in which a policy must be fixed and unchanging so as not to confuse the user and keep it running. In this case the communication process between the government and the community that conducts licensing usingOSS to carry out its licensing in accordance with the recommendations for processing licenses starting from Location permits, Business Licenses and Operational/commercial permits etc.

\section{METHODOLOGY}

This research used qualitative methods. Data collection techniques are triangulated. Data analysis is inductive, and the results of qualitative research emphasize meaning rather than generalization. Research has the purpose of describing certain social phenomena. In this case, the phenomenon to be described is the thing related to the Implementation of Electronic Licensing Business Services Integrated Policy. The approach used in describing the phenomenon is a case study that only applies to the case, does not apply to other cases.

The location of this research was conducted at JemberOne Stop Integrated Investment and Service Office, located at PB Sudirman Street, Pagah, Jemberlor, Patrang, Jember Regency, East Java 68118. i.e.theResearchers have time to research data both secondary and primary data during 2 (two) months starting in November 2018 until January 2019.

\section{Data Sources}

The data collection procedure used in this study is to group into two groups, namely:

1. Primary Data 
According to Sugiyono (2015: 137) primary data is a source of data that directly provides data to data collectors. Primary data was specifically collected to answer research questions. Primary data was obtained by observing and interviewing informants related to the research title. In addition, the primary data obtained through this interview was in the form of explanations and information needed by researchers from Jember's One Stop Investment and Integrated Services Service staff. As well as the results of direct observations regarding the implementation of licensing service policies trying to be integrated electronically with the Investment Services and One Stop Services in Jember.

\section{Secondary Data}

According to Sugiyono (2015: 137) secondary data is a source that does not directly provide data to data collectors. The data are in the form of Presidential Regulations, Government Regulations, Strategic Plans (Renstra) and data relating to licensing service policies that try to be integrated electronically such as the internet, journals etc.

D. Data Collection Method

According to Sugiyono (2005: 62), "The technique of data collection is the most strategic step in research, because the main purpose of research is to get data". Data collection in this study includes:

\section{Observation Technique}

According to Nawawi and Martini (1992: 74) Observation is the observation and recording systematically of the elements that appear in a symptom or symptoms in the object of research or can be said to be observational activities. Observation of researchers can find out the service process in the Investment and Integrated OneDoor Service given to the community, and researchers can find out what are some of the problems that are obstacles in the service. Symptoms in the service can be known by researchers through observations, namely observation of data by looking at SOP (Standard Operational Procedure), Regional Regulations and Regulations Regents in the agency.

2. Interview Technique 
According to Moleong (2010: 187) interviews are conversations with certain intentions. The conversation was conducted by two parties, namely the interviewer who asked the question and the interviewer who gave the answer to the question. The first interview was conducted with the head of the Jember One Stop Investment and Integrated Service, as well as the main thing in getting the data the researcher conducted an interview with the Service Section and Determination of Licensing. In terms of being able to know how far the Online Single Submission (OSS) System is implemented by Public Service providers in Jember $y$.

\section{Documentation Techniques}

According to Sugiyono (2013: 240), documentation can take the form of writing, images or momentary works from someone. Documentation is the collection of data by researchers by collecting documents from trusted sources who know about the resource person. This documentation technique is used to obtain secondary data, this technique is carried out by recording data sourced from archives, records, and reports on the implementation of the Integrated Integrated Electronic Licensing Services Policy in the Jember Regency One-Stop Investment and Integrated Service

Informants are people who are expected to provide information about the situation and background conditions of the study. Determination of informants in this study was carried out by purposive sampling technique, where the selection was done intentionally based on predetermined criteria and determined based on the objectives of the study.

Data analysis is an attempt to review the results that have been carried out by the category so that it can be used as a pattern that has relevance to the theories carried out in research, which are then determined by themes and work hypotheses to be formulated as suggested by the data. According to Miles and Huberman in Sugiyono(2012: 246) activities in data analysis are data reduction, data display, and conclusion drawing/verification and their understanding as follows:

1. Data Reduction (Data Reduction) 
Data Reduction means Reducing data means summarizing, choosing hah - the main thing, focusing on the important things, looking for themes and patterns. The data obtained from the field is quite numerous, therefore it needs to be carefully and detailed recorded. For this reason, it is necessary to analyze the data through data reduction. Reducing data means summarizing, choosing the main things, focusing on things that are important, looking for themes and patterns and discarding unnecessary ones. Thus the data that has been reduced will provide a clearer picture and facilitate the subsequent data collection.

\section{Data Display (Data Presentation)}

Presentation of data means After the data has been reduced, the next step is to display data. Data that has been compiled from the results of data reduction, then presented in the form of text that is narrative. Data presentation is an effort to compile a set of information into an easily understood form. The presentation of data that is easy to understand is the main way to analyze valid qualitative data.

\section{Conclusion Drawing (Conclusion)}

Conclusion means conclusions and verification. The conclusions in qualitative research are new findings that have never before existed. The initial conclusions put forward are still temporary and will change if no strong evidence is found that supports the next stage of data collection. But if the conclusions found at the beginning are supported by valid and consistent evidence when in the field to collect data, then the conclusions issued are credible conclusions so that this conclusion is expected to be able to find new findings that did not yet exist. The findings can be in the form of a description of what the image of an object before is still unclear, so that after being examined it becomes clear.

\section{Data Validity}

The validity of the data in research is often only emphasized in the validity and reliability test. In testing the validity of the data the researcher used the technique of checking the validity of the data, namely triangulation. According to Moleong (2010: 330) triangulation is a technique of checking the validity of data that utilizes something else. Triangulation is the most commonly used method in 
guaranteeing the validity of data in qualitative research. According to Sugiyono (2006: 273-274), explaining there are three types of triangulation, including the triangulation of sources, data collection, and time. And the method of triangulation method is done by comparing data obtained from the results of observations, interviews and documentation. Triangulation technique is done by comparing the research informants one with the other research informants.

\section{DISCUSSION}

The successful implementation of the policy are depend to 2 (two) factors in the Bureaucratic Structure, namely SOP (standard operational procedures) and Fragmentation. Electronic Integrated Business Licensing Services Policy InJember One Stop Investment Services and Integrated Services, there is no SOP for this policy, resulting in overlapping responsibilities of public service providers because the operators responsible for serving Online Single Submission (OSS) services also serve manually. Fragmentation in this policy is good because it involves Government Institutions or Online Single Submission (OSS) Institutions, namely Ministers, Heads of Institutions, Governors, or Regents/Mayors. Through the Online Single Submission (OSS) system, it can improve relations between the central government and regional governments.

Communication is one of the important variables in the implementation of the Integrated Electronic Licensing Services Policy. Communication, which is established between institutions namely ministers, leaders of institutions, governors, or regents/mayors is well intertwined with policy implementers, namely the one-stop integrated services (PTSP). In the delivery of the message carried out by the Jember One Stop Service and Integrated Investment Service to the community this was only in the form of a notification that included a list of licenses that could be accessed through the OSS application in the Jember PTSP. Licensing process that is through the OSS application can be accessed by anyone, anytime and anywhere. However, this has not yet achieved success, because many people have not yet understood how to enter data in OSS applications so it still 
caused the community and business people to go back and forth to the Jember District Investment and Integrated Services Office.

There are 3 (three) indicators in resources.First,Human Resources play an important role in the implementation of OSS in the Jember District Investment and Integrated Services One Door. One of the improvements in human resources is to follow technical guidance or training on OSS. In addition, the organizers of the Jember Regency One Stop Investment Service and Integrated Services Office also participated in the licensing related internship activities using OSS, and there were also activities aimed at increasing the institutional capacity of the Regional Work Unit (SKPD) placed in the investment service and integrated one-door service of Jember. However, based on the results of observations, the researchers found that the customer service staff or government apparatus have not fully mastered the OSS application because in its implementation. The second is budget resources and equipment resources.The policy one-stop integrated services have buildings, computers, Wi-Fi, Scanners, Printersetc.Then, the budget for implementing the OSS system comes from The Jember Revenue and Expenditure Budget,used to increase human resources in the OSS system and the provision of equipment needed in the OSS system. The third one is authority. Authority here is a separate force for the relevant OPD in the context of implementing OSS. This authority aims to assist businesses in processing one-stop integrated permits and services in Jember.

The attitude of the Public Service Provider in the Jember One Stop Investment Service and Integrated Service is in accordance with the service and the Standard Operating Procedure (SOP) is very good, because many people think that service providers are friendly, responsive and help the registration process to complete, namely by making e-mails for the elderly and also technologically educated.

Based on the conclusions obtained from this study, there are several suggestions that need to be considered, namely: 
1. Jember One Stop Investment Service and Integrated Service is expected to often socialize licensing using OSS which aims to allow business people who will proceed the permits to directly access this application, and can find out all the requirements needed to arrange permits. Then,there is no duplication of requests for requirements and in addition, with the re-socialization of business people, it is hoped that they do not understand the reciprocity of government offices only to obtain the required certificate at each stage of licensing.

2. The acceleration of licensing services integrated electronically is very good, however, local governments need to make regulations that can adjust to one-stop integrated services in each region.

3. The Jember One Stop Investment and Service Office is expected to be able to make an SOP to minimize overlapping responsibilities;so that there are no more providers serving 2 (two) services, namely online services and manual services.

4. The capacity of human resources of the Jember One Stop Investment and Service Office needs to be improved, so that in implementing this policy in accordance with their expertise. 
Integrated Licensing Policy With Electronic Policy: Study In The Department Of Capital Investment And Integrated Services Of Jember Indonesia

\section{Reference}

A.G, Subarsono, 2013, Analisis Kebijakan Publik. Yogyakarta: PustakaPelajar.

Nawi, H. Rusdin, 2017, Prilaku Kebijakan Organisasi. Makassar: Cv Sah Media

Surjadi, H. 2009, Pengembangan Kinerja PelayananPublik. Bandung: PT Refika Aditama.

Sugiyono, 2005, Memahami Penelitian Kualitatif.,Alfabeta: Jakarta.

Tahir, Arifin. 2015. KebijakanPublik dan TransparansiPenyelenggaraan

Pemerintah Daerah Bandung: Alfabeta.

Undang - UndangNomor 23 Tahun 2014 Pemerintahan Daerah.

Perturan Presiden Republik Indonesia Nomor 97 Tahun 2014 Tentang

Penyelenggaraan Pelayanan Terpadu SatuPintu

PeraturanPresidenNomor 91 Tahun 2017 tentang Percepatan Pelaksanaan

Berusaha.

PeraturanPemerintahNomor 28 Tahun 2018 tentang Pelayanan Perizinan Berusaha Terintegrasi Secara Elektronik.

Peraturan Daerah Kabupaten Jember Nomor 3 Tahun 2016 tentang Pembentukan dan Susunan Perangkat Daerah.

PeraturanBupatiJemberNomor 56 Tahun 2016 tentang Kedudukan,

SusunanOrganisasi, Tugas dan Fungsi serta Tata Kerja Dinas

Penanaman Modal dan Pelayanan Terpadu Satu Pintu Kabupaten

Jember.

\section{Internet}

https://www.oss.go.id/oss/\# (diaksestanggal 29 Desember 2018)

https://www.oss.go.id/oss/portal/download/f/s-463.pdf (diaksestanggal 30

Desember 2018) 